\title{
USULAN PERBAIKAN \\ TATA LETAK FASILITAS PRODUKSI INDUSTRI KOPI STUDI KASUS CV. TRI ANOM AGROTEKTUR
}

\author{
Nabilla Saptaryana Martha ${ }^{1 *}$ dan Irfan Ardiansah ${ }^{2}$ \\ ${ }^{1,2}$ Dept.Teknologi Industri Pertanian, Fak. Teknologi Industri Pertanain, Universitas Padjadjaran \\ Jln. Raya Bandung-Sumedang Km. 21. Jatinangor, Kab. Sumedang 45363. Jawa Barat. \\ *email: Nabilla15006@mail.unpad.ac.id
}

\begin{abstract}
Industrial layout is one of the important factors that affecting the efficiency of the production operation process, which can be seen from the material movement activities to be processed into products. CV. Tri Anom Agrotektur manages the coffee industry which is divided into 2 activity sectors, namely the upstream and downstream sectors. This study designed a proposal to improve the factory layout of the company's upstream sector using qualitative methods and direct interviews with factory employees. In determining the layout improvement of the industry, it is necessary to first identify the production process, using the Process Flow Diagram and Process Flow Map. The data processing methods used are: Activity Relationship Chart (ARC), Activity Relationship Diagram (ARD), and Activity Allocation Diagram (AAD). Total area of the factory building is \pm $1.072 \mathrm{~m}^{2}$, while the proposed total area of the building based on the area of the machine, the area of the employee's movement and the additional area of production support room is $\pm 833 \mathrm{~m}^{2}$. The total proposed rooms are 23 rooms. Proposed improvements to the industrial layout can be use as company reference that is expected to increase productivity and reduce production costs.
\end{abstract}

Keywords: Layout, Industry, Coffee

\section{Pendahuluan}

Indonesia memiliki peluang dalam pengembangan industri pengolahan kopi. Hal ini didukung dengan potensi bahan baku yang meningkat dan memiliki peluang pasar yang besar. Kopi merupakan komoditi hasil perkebunan yang memiliki peranan penting dalam kegiatan perekonomian di Indonesia. Menurut Badan Pusat Statistik Indonesia (2018), untuk Perkebunan Rakyat (PR), produksi dari tahun 2016 sampai 2018 cenderung mengalami peningkatan setiap tahun. Produksi pada tahun 2016 sekitar 632,00 ribu ton, pada tahun 2017 menjadi 685,80 ribu ton atau meningkat 8,51 persen. Pada tahun 2018 mencapai 685,79 ribu ton atau turun 0,002 persen dibandingkan dengan tahun 2017. Seiring dengan meningkatnya bahan baku dari komoditi kopi, akan banyak juga produsen kopi di Indonesia. Dibutuhkan strategi dalam meningkatkan produktivitas industri yang optimum dan mengurangi biaya produksi yang dikeluarkan.

Kadatuan Koffie merupakan suatu merek yang dikelola oleh CV. Tri Anom Agrotektur. Perusahaan ini mengolah komoditas kopi yang terbagi kedalam 2 sektor produksi, yaitu sektor hulu dan sektor hilir. Penelitian ini dilakukan pada sektor hulu perusahaan, yaitu mengolah kopi dari proses panen hingga produk green bean kopi. Pada sektor hulu, terdapat kebun kopi, pabrik, dan tempat penyimpanan sementara. Menurut (Rahman \& Rahmah, 2018), dalam identifikasi proses dan strategi bisnis perusahaan menggunakan analisis SWOT, salah satu faktor kelemahan internal pada perusahaan yaitu mesin pengupas biji kopi memiliki kebisingan yang tinggi dalam sebuah ruangan dan belum ada SOP tertulis terhadap pekerja dan terhadap proses pengolahan kopi. Salah satu strategi yang dapat diterapkan menggunakan strategi WT, yaitu menekan biaya produksi dengan melakukan efisiensi di setiap proses produksi.

Tata letak fasilitas produksi mempunyai faktor penting tehadap proses produksi, terutama ditinjau dari segi perpindahan material hingga proses akhir produksi. Hal ini terlihat aktivitas pemindahan sekurang-kurangnya satu dari tiga elemen dasar sistem produksi, meliputi bahan baku, orang (pekerja) dan peralatan produksi. Oleh karena itu perlu adanya suatu pertimbangan bagaimana membuat atau mendesain tata letak fasilitas yang lebih efektif dan efesien (Purnomo, Rudianto, \& Hamdani, 2012). Dengan usulan perbaikan tata letak fasilitas produksi ini, 
diharapkan dapat meningkatkan produktivitas yang efektif dan efisien.

\section{Landasan Teori}

\subsection{Tata Letak (Layout)}

Dalam meningkatkan produktivitas dan mengurangi ongkos produksi, diperlukannya suatu tools untuk mengatur dalam meletakan setiap elemen agar dapat berjalan dengan efektif dan efisien. Tata letak fasilitas dapat difenisikan sebagai perancangan fasilitas yang mengatur unsur-unsur fisik berupa alat/mesin, bangunan dan sebagainya (Winarno, 2015). Jarak perpindahan material yang jauh akan menyebabkan rentang waktu yang dibutuhkan cukup tinggi, sehingga dapat menyebabkan tingginya biaya produksi yang dikeluarkan. Dengan mengurangi jarak perpindahan material, akan mengurangi pemborosan waktu produksi (Handoko, 2013).

\subsection{Perancangan Tata Letak}

Perancangan tata letak fasilitas produksi industri ini menggunakan tiga metode, yaitu: Activity Relationship Chart (ARC), Activity Relationship Diagram (ARD), dan Area Allocation Diagram (AAD). Menurut Wignjosoebroto (2009), ARC merupakan nilainilai yang menunjukan derajat kedekatan hubungan suatu aktivitas produksi. Dalam pembuatan ARC ini memiliki komposisi derajat kedekatan antar fasilitas produksi A, E, I, O, U, dan $\mathrm{X}$ yang secara berurutan berarti mutlak berdekatan, sangat penting berdekatan, penting berdekatan, cukup/biasa berdekatan, tidak penting berdekatan, dan tidak dikehendaki berdekatan. untuk mengetahui tingkat hubungan sebuah pusat kegiatan atau fasilitas satu dengan yang lainnya. Hasil dari ARC akan didapat Tabel Sekala Prioritas (TSP) yang berupa tabel dengan tujuan untuk menggambarkan urutan prioritas yang paling terpenting untuk peletakan antar fasilitas produksi dalam satu lintasan pada layout pabrik.

TSP kemudian diolah dengan metode selanjutnya yaitu ARD. Menurut Apple (1990), ARD merupakan diagram balok yang menunjukan pendekatan keterkaitan kegiatan, menunjukan setiap kegiatan sebagai suatu model kegiatan tunggal. Tujuan dari ARD ini adalah sebagai dasar perencanaan keterkaitan antara pola aliran barang dan lokasi kegiatan pendukung produksi dihubungkan dengan kegiatan produksi. Pada analisis ARD ini dilakukan 2 kali analisis, yaitu analisis ARD awal sesuai dengan kondisi pabrik saat ini dan analisis ARD usulan perbaikan sesuai dengan pertimbangan sekala prioritas antar fasilitas produksi.

Analisis perancangan berikutnya menggunakan metode AAD dimana sudah diketahui kesimpulan tingkat kedekatan antar aktivitas. AAD ini menentukan aktivitas mana yang harus dekat dengan aktivitas lainnya atau sebaliknya harus dijauhkan dengan aktivitas lainnya atau dapat dikatakan bahwa hubungan antar aktivitas mempengaruhi tingkat kedekatan antar tata letak aktivitas tersebut (Arif, 2017).

\section{Metode Penelitian}

Penelitian ini merupakan penelitian kualitatif dimana jenis data yang digunakan yaitu data sekunder, sumber data diperoleh dari observasi di lapangan dan wawancara langsung kepada pegawai pabrik dan kepada Chief Executive Officer (CEO) perusahaan. Batasan dari penelitian ini variabel jarak dan waktu proses produksi tidak dihitung secara detail, namun diperhitungkan berdasarkan ukuran setiap area atau ruangan.
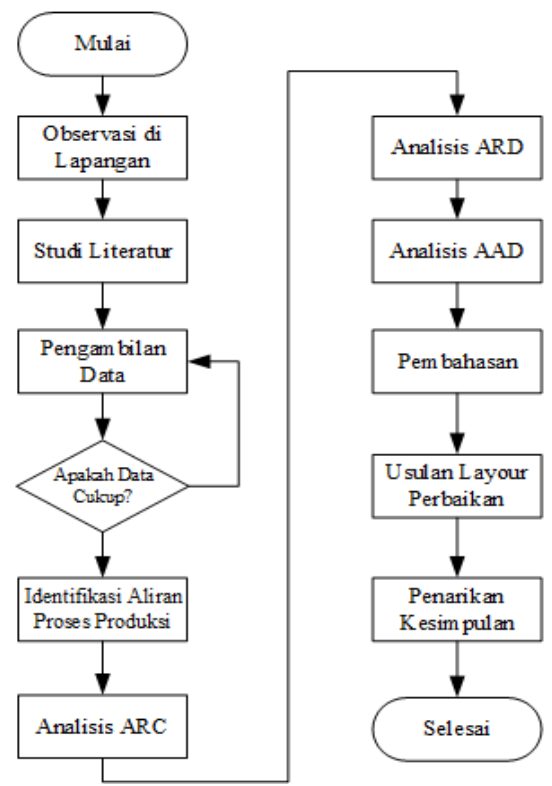

Gambar 1. Diagram Alir Penelitian

\section{Hasil dan Pembahasan}

\subsection{Lokasi Geografis Industri}

Sektor hulu CV. Tri Anom Agrotektur beralamat di Desa Mekarsari, Kampung Cipeutey RT 2 RW 11, Kecamatan Cimaung, Kabupaten Bandung. Sektor hulu perusahaan terdapat kebun kopi, pabrik pengolahan kopi, dan gudang 
sementara. Area kebun dan pabrik perusahaan berada di sekitar titik koordinat lintang -7.106063 dan titik koordinat bujur 107.571288. Sedangkan untuk ketinggian daerah kebun berada pada ketinggian \pm 940 mdpl. Garis merah pada gambar 2 menunjukan batasan area kebun yang memiliki luasan $\pm 5,5$ hektar.

\subsection{Identifikasi Proses Aliran Produksi}

Untuk menentukan perbaikan tata letak pabrik, identifikasi proses produksi ini sangat diperlukan, karena harus diketahui detail kegiatan produksi dari awal proses hingga produk akhir. Identifikasi proses produksi juga dapat sebagai dasar pertimbangan untuk menentukan dan memperhitungkan luas area tiap proses produksi. Identifikasi proses produksi terdiri dari diagram aliran proses dan peta aliran proses

Diagram Aliran Proses bertujuan untuk untuk menggambarkan suatu bagan aliran proses produksi secara sistematis dan logika. Bagan ini menjelaskan urutan-urutan dari prosedur-prosedur yang ada di dalam sistem. Dimulai dengan proses panen buah kopi yang berasal dari kebun perusahaan, kemudian menghasilkan produk akhir berupa green bean Kopi yang sudah digolongkan.

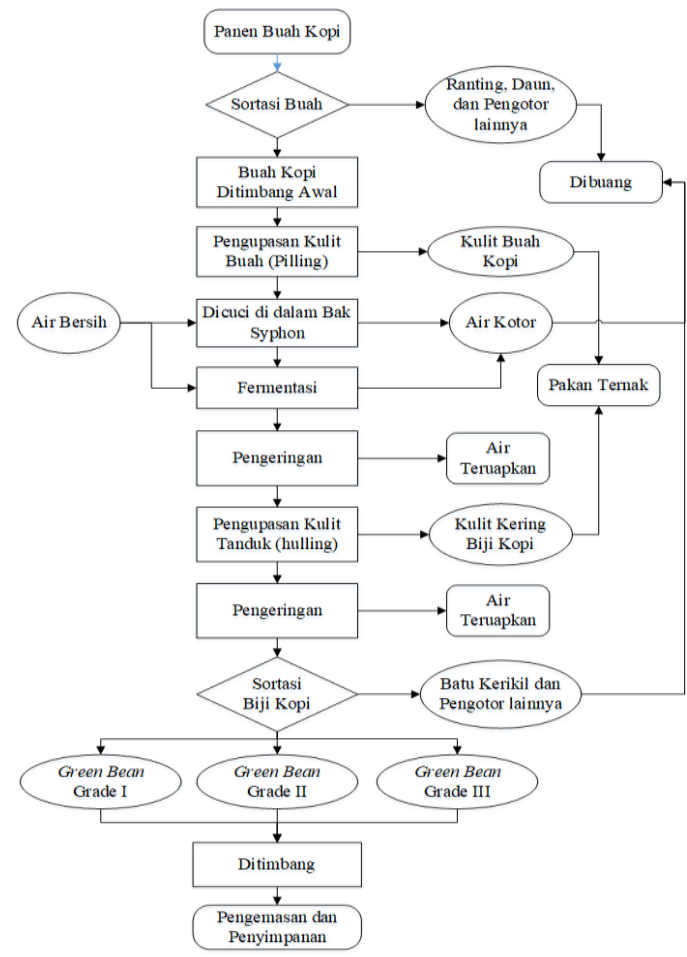

Gambar 2. Diagram Aliran Proses Produksi

Peta Aliran Proses bertujuan untuk menggambarkan semua aktivitas, baik aktivitas yang produktif seperti operasi atau inspeksi maupun tidak produktif seperti transportasi, menunggu, dan menyimpan. Kegiatan dalam peta aliran proses ini diuraikan secara detail dari awal hingga akhir proses.

Tabel 1. Peta Aliran Proses Produksi

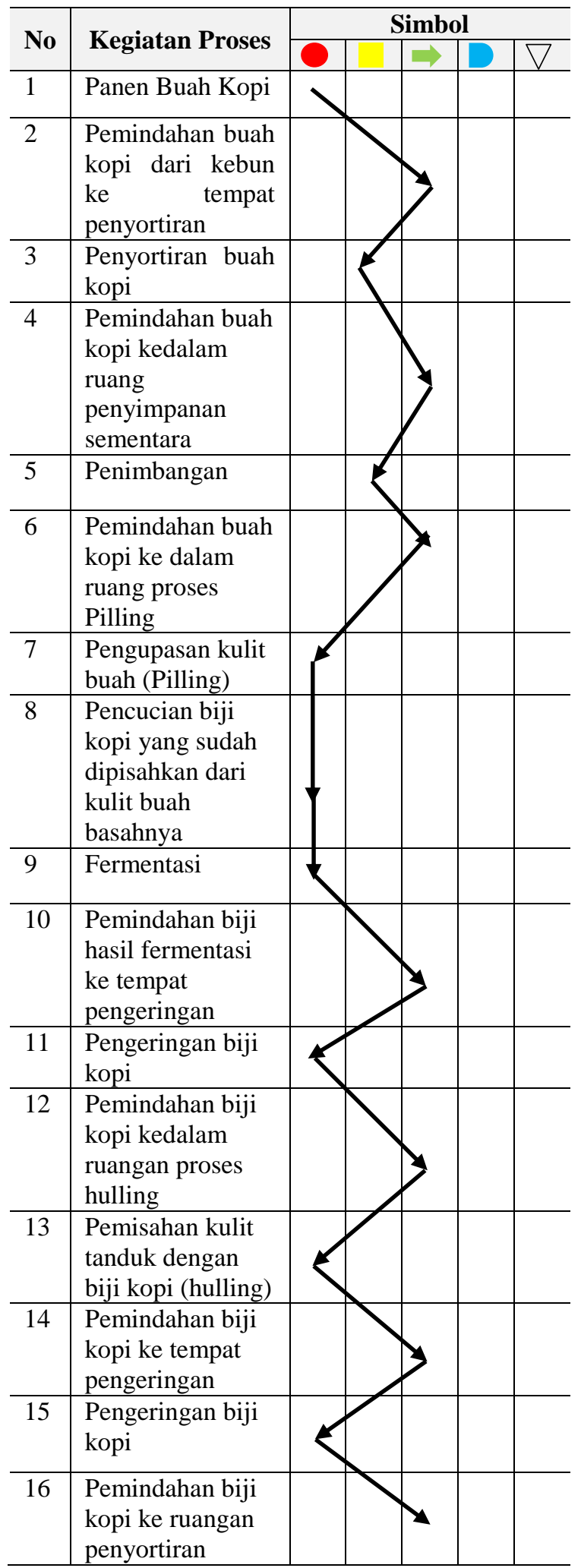




\begin{tabular}{c|l|l|l|l|l|l}
\hline 17 & $\begin{array}{l}\text { Penyortiran biji } \\
\text { kopi }\end{array}$ & & & & & \\
\hline 18 & $\begin{array}{l}\text { Pemindahan ke } \\
\text { tempat } \\
\text { penyimpanan }\end{array}$ & & & & & \\
\hline 19 & Penimbangan & & & & \\
\hline 20 & Penyimpanan & & & & \\
\hline
\end{tabular}

Sumber: Pengolahan Data

Pada peta aliran proses produksi green bean kopi ini menunjukan banyaknya operasi sebanyak 7 kali operasi. Banyaknya pemeriksaan yang dilakukan sebanyak 4 kali pemeriksaan. Banyaknya perpindahan sebanyak 8 kali perpindahan. Dalam peta aliran proses produksi ini tidak ditemukan penundaan selama produksi. Sedangkan untuk proses penyimpanan, terdapat 1 kali penyimpanan. Namun banyak ditemukan proses perpindahan dari suatu ruangan ke ruangan lain untuk melanjutkan prosesnya. Hal ini menunjukan bahwa masih terdapat kegiatan yang kurang efektif selama produksi yang dikarenakan tata letak ruangannya dan akan berdampak pada waktu, biaya, serta tenaga selama produksi.

Tabel 2 . Keterangan Simbol Peta Aliran Proses

\begin{tabular}{ccc}
\hline No. & Simbol & Penjelasan Simbol \\
\hline 1 & & Operasi \\
2 & & Pemeriksaan \\
3 & $\Rightarrow$ & Perpindahan \\
4 & $D$ & Penundaan \\
5 & $\nabla$ & Penyimpanan \\
\hline
\end{tabular}

\subsection{Alat dan Mesin}

Berikut daftar mesin dan alat yang digunakan peruasahaan dalam produksi kopi.

Tabel 3. Alat dan Mesin Produksi

\begin{tabular}{cccc}
\hline No. & $\begin{array}{c}\text { Nama } \\
\text { Alat/Mesin }\end{array}$ & $\begin{array}{c}\text { Dimensi } \\
\text { (meter) }\end{array}$ & $\begin{array}{c}\text { Banyak } \\
\text { Mesin/ } \\
\text { Alat }\end{array}$ \\
\hline 1 & Keranjang & $\begin{array}{c}\mathrm{D}=0,45 \\
\mathrm{~T}=0,8\end{array}$ & 4 \\
2 & Pulper & $1,5 \times 0,8 \times 1,5$ & 2 \\
3 & Bak Syphon & $2 \times 1,2 \times 1$ & 2 \\
4 & Huller & $2,5 \times 2 \times 1,4$ & 1 \\
5 & $\begin{array}{c}\text { Timbangan } \\
\text { Gantung }\end{array}$ & $1 \times 0,1 \times 0,3$ & 1 \\
\hline
\end{tabular}

\begin{tabular}{cccc}
\hline 6 & $\begin{array}{c}\text { Timbangan } \\
\text { Duduk } \\
\text { Digital }\end{array}$ & $\begin{array}{c}0,55 \times 0,55 \times \\
0,9\end{array}$ & 1 \\
\hline 7 & Bilik Bambu & $5 \times 2,5 \times 0,01$ & 7 \\
\hline 8 & $\begin{array}{c}\text { Terpal } \\
\text { plastik }\end{array}$ & $4 \times 6 \times 0,01$ & 6 \\
\hline
\end{tabular}

\subsection{Pertimbangan Luas Area/Ruang Keperluan Produksi}

Bangunan pabrik memiliki tiga tingkatan lantai yang masing-masing lantai dipakai untuk produksi dan tempat istirahat bagi para pegawai. Yang harus diperhatikan dalam menentukan tata letak suatu pabrik yaitu luas area dari masingmasing proses, tempat persediaan bahan, dan ruang gerak bagi para pegawai untuk mengoperasikan suatu alat ataupun mesin. Pertimbangan luas area dan ruang untuk kegiatan produksi adalah sebagai tabel berikut.

Tabel 4. Pertimbangan Luas Area/Ruangan Produksi

\begin{tabular}{|c|c|c|c|c|}
\hline \multirow[b]{3}{*}{ No } & \multirow[b]{3}{*}{$\begin{array}{c}\text { Nama } \\
\text { Area/Ruang }\end{array}$} & \multicolumn{3}{|c|}{ Dimensi Area/Ruang (pxl) } \\
\hline & & & Usul & \\
\hline & & $\begin{array}{c}\text { Saat } \\
\text { Ini (m) }\end{array}$ & $\begin{array}{c}\text { Berdasark- } \\
\text { an } \\
\text { Alat/Mesin } \\
\text { + Ruang } \\
\text { Gerak } \\
\end{array}$ & $\begin{array}{c}\text { Luas } \\
\text { Akhir }\end{array}$ \\
\hline 1 & $\begin{array}{l}\text { Penyortiran } \\
\text { Buah Kopi }\end{array}$ & $8 \times 7$ & $7 \times 5$ & 35 \\
\hline 2 & $\begin{array}{l}\text { Penyimpana- } \\
\text { n Sementara }\end{array}$ & $15 \times 8$ & $13 \times 5$ & 65 \\
\hline 3 & R. Pilling & $8 \times 2$ & $6 \times 1,8$ & 10,8 \\
\hline 4 & $\begin{array}{l}\text { Pencucian \& } \\
\text { Fermentasi }\end{array}$ & $8 \times 5$ & $6 \times 2,2$ & 13,2 \\
\hline 5 & $\begin{array}{l}\text { Area } \\
\text { Pengeringan }\end{array}$ & $18 \times 7$ & $18 \times 7$ & 126 \\
\hline 6 & Hulling & $5 \times 5$ & $5 \times 5$ & 25 \\
\hline 7 & $\begin{array}{l}\text { Penyortiran } \\
\text { Biji Kopi }\end{array}$ & $10 x 4$ & $10 \times 4$ & 40 \\
\hline 8 & $\begin{array}{l}\text { Penyimpana- } \\
\text { n Produk I }\end{array}$ & $4 \times 3,5$ & $4 \times 3,5$ & 14 \\
\hline 9 & $\begin{array}{l}\text { Penyimpana- } \\
\text { n Produk II }\end{array}$ & $8 \times 6$ & $4 \times 3,5$ & 14 \\
\hline 10 & $\begin{array}{l}\text { Penyimpana } \\
\text { n Peralatan }\end{array}$ & $5 \times 5$ & $5 \times 5$ & 25 \\
\hline 11 & Tamu & $4 \times 3$ & $4 \times 3$ & 12 \\
\hline 12 & Dapur & $3 \times 2$ & $3 \times 2$ & 6 \\
\hline 13 & Mushola & $2 \times 2$ & $3 \times 3$ & 9 \\
\hline 14 & Toilet I & $2 \times 1$ & $2 \times 2$ & 4 \\
\hline 15 & Toilet II & $2 \times 1$ & $2 \times 2$ & 4 \\
\hline 16 & Pegawai I & $3 \times 4$ & $3 \times 4$ & 12 \\
\hline 17 & Pegawai II & $2 \times 4$ & $3 \times 4$ & 12 \\
\hline 18 & Area Limbah & $8 \times 2$ & $8 \times 2$ & 16 \\
\hline 19 & Area Parkir & $10 \times 5$ & $10 \times 5$ & 50 \\
\hline 20 & $\begin{array}{l}\text { Area Kosong } \\
\text { I }\end{array}$ & $5 \times 6$ & $5 \times 6$ & 30 \\
\hline
\end{tabular}




\begin{tabular}{lllll}
21 & $\begin{array}{l}\text { Area Kosong } \\
\text { II }\end{array}$ & $\begin{array}{l}15 \times 1 \\
8\end{array}$ & $15 \times 18$ & 270 \\
\hline Total & 1072 & Total & 793 \\
\hline
\end{tabular}

Pabrik kopi CV Tri Anom Agrotektur memiliki jumlah ruangan dan area sebanyak 21 ruangan. Dari 21 ruangan tersebut ditemukan 2 ruangan kosong dan ruangan yang terlalu besar untuk proses produksi. Hal ini masih dapat dimanfaatkan dengan area/ruangan pendukung proses produksi.Oleh karena itu diperlukan perbaikan tata letak dari area/ruangan yang terdapat pada pabrik tersebut.

\subsection{Usulan Penambahan Area dan Ruangan Keperluan Pendukung}

Dari keseluruan luas area dan ruangan yang terdapat pada pabrik kopi CV Tri Anom Agrotektur, ditemukan sisa luasan yang dapat dimanfaatkan sebagai area ataupun ruangan pendukung produksi. Jika diketahui luasan total dari bangunan pabrik tersebut yaitu $\pm 1.072 \mathrm{~m}^{2}$, ternyata berdasarkan tabel 7 pertimbangan luas area dan ruangan keperluan proses menunjukan total luas yang diusulkan sebesar $\pm 793 \mathrm{~m}^{2}$ dan masih ada sisa dari luas keseluruhan bangunan sebesar $\pm 279 \mathrm{~m}^{2}$. Sisa dari luasan bangunan tersebut masih dapat dimanfaatkan untuk menambahkan area atau ruangan baru. Berikut penambahan ruangan yang diusulkan untuk keperluan pendukung produksi.

Tabel 5. Usulan Penambahan Area dan Ruangan Pendukung Produksi

\begin{tabular}{|c|c|c|c|}
\hline \multirow[b]{2}{*}{ No. } & \multicolumn{3}{|c|}{ Usulan } \\
\hline & $\begin{array}{l}\text { Area/ Ruang } \\
\text { Keperluan } \\
\text { Pendukung }\end{array}$ & $\begin{array}{c}\text { Dimensi } \\
\text { Area/ } \\
\text { Ruang } \\
(\mathbf{p} \times \mathbf{l})(\mathbf{m}) \\
\end{array}$ & $\begin{array}{c}\text { Luas } \\
\text { Area/ } \\
\text { Ruang } \\
\left(\mathbf{m}^{2}\right) \\
\end{array}$ \\
\hline 1 & $\begin{array}{l}\text { Area Pempungan } \\
\text { Air Bersih }\end{array}$ & $2 \times 2$ & 4 \\
\hline 2 & Kantor & $4 \times 3$ & 12 \\
\hline 3 & $\begin{array}{l}\text { Area Loading } \\
\text { Barang }\end{array}$ & $10 \times 2$ & 20 \\
\hline 4 & $\begin{array}{c}\text { Penyimpanan } \\
\text { BBM }\end{array}$ & $2 \times 2$ & 4 \\
\hline & Total & & 40 \\
\hline
\end{tabular}

Dijumlahkan dengan total luasan pada tabel 4 dengan tabel 5, maka didapat usulan luas akhir bangunan pabrik sebesar $833 \mathrm{~m}^{2}$.

\subsection{Activity Relationship Chart (ARC)}

Pada ARC ini bertujuan untuk membantu menggambarkan kegiatan produksi dari suatu pabrik. Semua kegiatan produksi dari pabrik tersebut harus memiliki hubungan yang terikat dari suatu kegiatan dengan kegiatan lainnya yang dianggap penting dan harus selalu berdekatan demi mendapatkan hasil produksi yang efektif dan efisien. Selain kegiatan tersebut harus berdekatan, ada juga yang harus dijauhkan dari kegiatan lainnya. Oleh sebab itu harus dibuat suatu peta hubungan aktifitas, dimana akan diketahui bagaimana hubungan yang terjadi dan harus dipenuhi sesuai dengan kegiatan dan hubungan lainnya yang mendukung. Gambar ARC pabrik terlampir pada lampiran 1 .

Pada ARC yang terlampir terdapat simbol huruf yang menunjukan derajat kedekatan antara area atau ruang satu dengan area atau ruang yang lainnya. Seperti contohnya ruang penyortiran buah kopi yang mutlak berdekatan dengan ruang penyimpanan sementara. Hal ini jika tidak berdekatan akan berdampak pada bertambahnya handling, biaya, tenaga dan waktu produksi. Selain harus mutlak berdekatan, ada juga yang harus diletakan tidak dikehendaki berdekatan dengan ruangan lainnya. Seperti contohnya ruang pegawai dengan area limbah. Hal ini juga berdekatan akan mengganggu aktivitas dari ruangan lainnya.

\subsection{Tabel Sekala Prioritas (TSP)}

Setelah penyusunan ARC, kemudian dibuatkan TSP yang berupa tabel dengan tujuan untuk menggambarkan urutan prioritas untuk yang paling terpenting antar departemen atau mesin dalam satu lintasan pada layout pabrik.

Tabel 6. Tabel Sekala Prioritas

\begin{tabular}{|c|c|c|c|c|c|}
\hline \multirow{2}{*}{$\begin{array}{l}\mathbf{N} \\
\mathbf{o .}\end{array}$} & \multirow{2}{*}{$\begin{array}{c}\text { Nama } \\
\text { Ruangan/ } \\
\text { Area }\end{array}$} & \multirow{2}{*}{$\begin{array}{c}\text { Kod } \\
\text { e }\end{array}$} & \multicolumn{3}{|c|}{ Skala Prioritas } \\
\hline & & & I & II & III \\
\hline 1 & $\begin{array}{r}\text { Penyortiran } \\
\text { Buah Kopi }\end{array}$ & A & B & $\mathrm{P}$ & $\mathrm{C}$ \\
\hline 2 & $\begin{array}{l}\text { Penyimpana } \\
\text { n Sementara }\end{array}$ & B & $\mathrm{A}, \mathrm{C}$ & & $\mathrm{D}, \mathrm{E}, \mathrm{F}, \mathrm{G}$ \\
\hline 3 & Pilling & $\mathrm{C}$ & $\mathrm{B}, \mathrm{D}, \mathrm{P}$ & $\mathrm{R}$ & $\mathrm{A}, \mathrm{V}$ \\
\hline 4 & $\begin{array}{l}\text { Pencucian } \\
\text { dan } \\
\text { Fermentasi }\end{array}$ & $\mathrm{D}$ & $\mathrm{C}, \mathrm{E}$ & $\mathrm{P}, \mathrm{R}$ & B \\
\hline 5 & $\begin{array}{c}\text { Area } \\
\text { Pengeringan }\end{array}$ & $\mathrm{E}$ & $\mathrm{D}, \mathrm{F}$ & & $\mathrm{B}, \mathrm{J}$ \\
\hline
\end{tabular}




\begin{tabular}{|c|c|c|c|c|c|}
\hline 6 & Hulling & F & E,G,P & & $\mathrm{R}, \mathrm{V}$ \\
\hline 7 & $\begin{array}{c}\text { Penyortiran } \\
\text { Biji Kopi }\end{array}$ & G & $\mathrm{F}, \mathrm{H}, \mathrm{I}$ & $\mathrm{P}$ & B \\
\hline 8 & $\begin{array}{c}\text { Penyimpana } \\
\text { n Produk } \\
\text { Akhir I }\end{array}$ & $\mathrm{H}$ & $\mathrm{G}, \mathrm{U}$ & I & S \\
\hline 9 & $\begin{array}{c}\text { Penyimpana } \\
\text { n Produk } \\
\text { Akhir II }\end{array}$ & I & $\mathrm{G}, \mathrm{U}$ & $\mathrm{H}$ & S \\
\hline 10 & $\begin{array}{l}\text { Penyimpana } \\
\text { n Peralatan } \\
\text { Tani }\end{array}$ & $\mathrm{J}$ & & & $\mathrm{E}$ \\
\hline 11 & Tamu & $\mathrm{K}$ & & M & $\begin{array}{c}\mathrm{Q}, \mathrm{S}, \mathrm{T}, \\
\mathrm{W}\end{array}$ \\
\hline 12 & Dapur & $\mathrm{L}$ & & & $\begin{array}{c}\mathrm{N}, \mathrm{O}, \mathrm{T} \\
\mathrm{W}\end{array}$ \\
\hline 13 & Moshola & M & & $\mathrm{K}$ & $\begin{array}{c}\text { N,O,S,T } \\
\text {,W }\end{array}$ \\
\hline 14 & Pegawai I & $\mathrm{N}$ & & & $\begin{array}{c}\mathrm{L}, \mathrm{M}, \mathrm{T} \\
\mathrm{W}\end{array}$ \\
\hline 15 & Pegawai II & $\mathrm{O}$ & & & $\begin{array}{c}\mathrm{L}, \mathrm{M}, \mathrm{T}, \\
\mathrm{W}\end{array}$ \\
\hline 16 & $\begin{array}{c}\text { Area } \\
\text { Limbah }\end{array}$ & $\mathrm{P}$ & $\begin{array}{c}\mathrm{A}, \mathrm{C}, \mathrm{D} \\
, \mathrm{F}, \mathrm{G}\end{array}$ & & $\mathrm{Q}, \mathrm{T}, \mathrm{W}$ \\
\hline 17 & $\begin{array}{c}\text { Area Parkir } \\
\text { Kendaraan } \\
\text { Area }\end{array}$ & Q & $\mathrm{U}$ & & $\mathrm{K}, \mathrm{V}$ \\
\hline 18 & $\begin{array}{c}\text { Penampung } \\
\text { an Air } \\
\text { Bersih }\end{array}$ & $\mathrm{R}$ & & C,D & $\mathrm{F}, \mathrm{T}, \mathrm{W}$ \\
\hline 19 & Kantor & $\mathrm{S}$ & & & $\begin{array}{c}\mathrm{H}, \mathrm{I}, \mathrm{K}, \mathrm{M} \\
\text {,T,W }\end{array}$ \\
\hline 20 & Toilet I & $\mathrm{T}$ & & & $\begin{array}{c}\text { K,L,M, } \\
\text { N,O,P,R } \\
\text {,S }\end{array}$ \\
\hline 21 & $\begin{array}{c}\text { Area } \\
\text { Loading } \\
\text { Barang }\end{array}$ & $\mathrm{U}$ & $\mathrm{I}, \mathrm{J}, \mathrm{Q}$ & & \\
\hline 22 & $\begin{array}{c}\text { Penyimpana } \\
\text { n BBM }\end{array}$ & V & & & $\mathrm{C}, \mathrm{F}, \mathrm{Q}$ \\
\hline 23 & Toilet II & W & & & $\begin{array}{c}\mathrm{K}, \mathrm{L}, \mathrm{M}, \\
\mathrm{N}, \mathrm{O}, \mathrm{P}, \mathrm{R} \\
, \mathrm{S}\end{array}$ \\
\hline
\end{tabular}

\subsection{Activity Relationship Diagram (ARD)}

Dalam penyusunan ARD atau diagram hubungan antar aktivitas bertujuan untuk meminimumkan ongkos handling dari departemen atau mesin dalam kegiatan produksi. Dasar untuk membuat ARD yaitu TSP, jadi yang menempati prioritas pertama pada TSP harus didekatkan letaknya lalu diikuti prioritas berikutnya. Terdapat balok-balok yang menunjukan departemen proses yang dihubungi oleh berbagai macam garis dan warna garis. Berikut keterangan garis dan warna pada ARD. Tiga garis berwarna merah menunjukan skala prioritas pertama yang mutlak berdekatan antara departemennya. Hal ini mendukung meminimalkan handling, waktu, dan ongkos produksi. Dua garis berwarna kuning menunjukan skala prioritas kedua. Sedangkan satu garis berwarna hijau menjadi skala prioritas ketiga atau terakhir. ARD awal dibuat berdasarkan skala prioritas yang sudah ditetapkan pada TSP sebelumnya, diwakilkan dengan garis berwarna sebagai gambaran tingkatan kedekatan area dan ruang. Garis berwarna tersebut menghubungkan tiap elemen dan menggambarkan bagaimana skala prioritas kedekatan antar elemen. ARD 1 pabrik kopi CV Tri Anom Agrotektur pada gambar 3.

Pola aliran bahan yang digambarkan pada ARD awal atau pada gambar 3 termasuk pola aliran zig-zag berdasarkan kedekatan tiap ruang

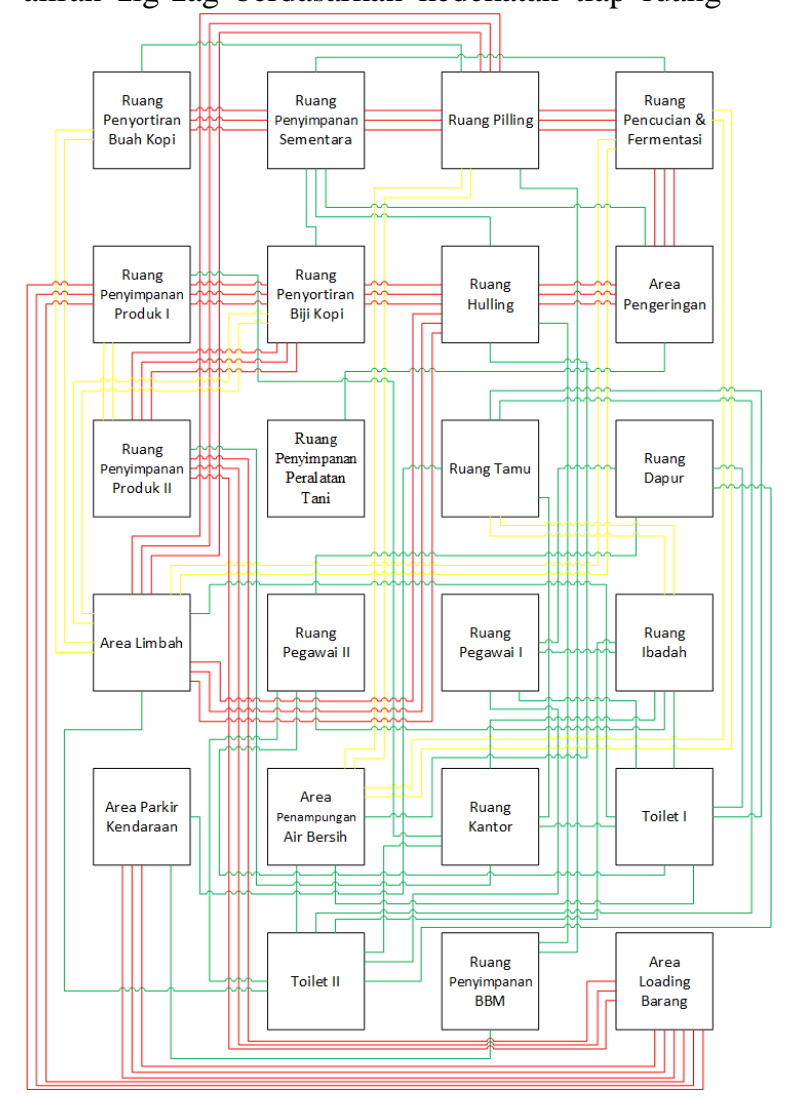

Gambar 3. Activity Relationship Diagram Awal

dan area yang memiliki skala prioritas I yang dilambangkan dengan 3 garis merah. Area atau ruangan yang dihubungkan dengan 3 garis merah harus diletakan berdekatan dengan tujuan meningkatkan produktivitas berdasarkan jarak perpindahan material. Seperti contohnya ruang pilling dan ruang hulling dengan area limbah. Dan 
contoh lainnya adalah ruangan penyimpanan produk akhir dengan area loading barang dan area parkir kendaraan. Kedua ruangan tersebut saling berjauhan. Begitu juga dengan area atau ruangan yang dihubungkan dengan 2 garis kuning dan 1 garis hijau yang harus dilekatakan berdasarkan pertimbangan skala prioritas produksi. Oleh karena itu diperlukannya perubahan dari ARD. Dalam perbaikan ARD ini memperhatikan faktorfaktor jarak perpindahan material antara area atau ruangan, ketersediaan ukuran area atau ruangan yang sudah ada, aktivitas dari produksi yang dapat mengganggu pada area atau ruangan lainnya. Dari ketiga faktor tersebut akan dicari perbaikan layout pabrik yang paling baik. Berikut usulan perbaikan ARD perusahaan produksi green bean Kopi.

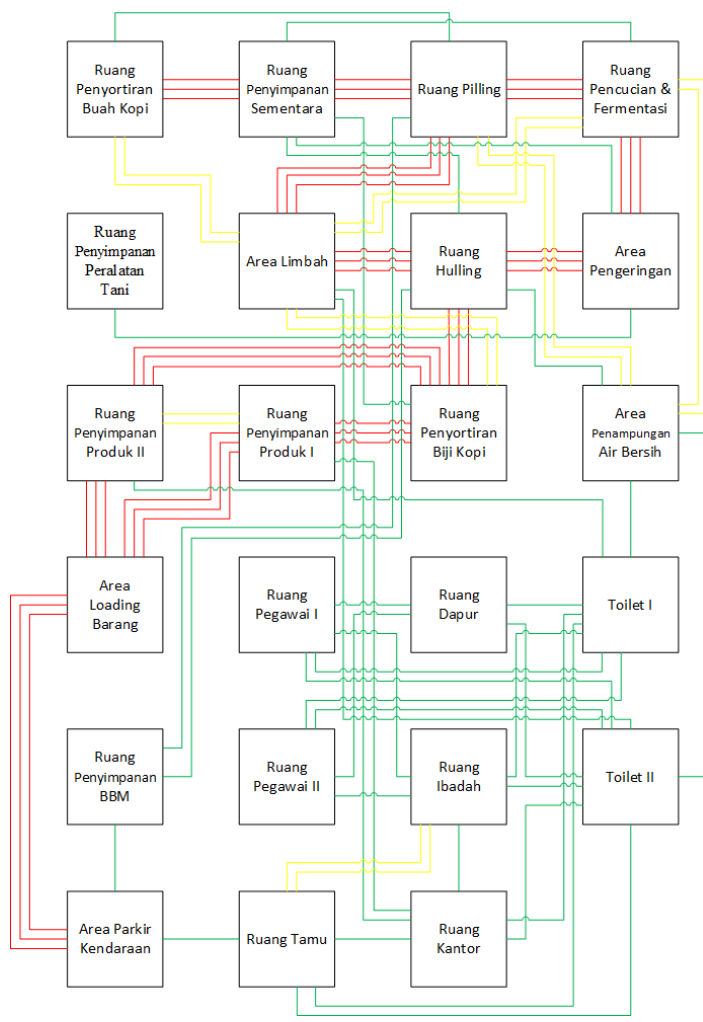

Gambar 4. Activity Relationship Diagram Perbaikan

Pada gambar ARD perbaikan ini merupakan ARD perbaikan dari ARD awal. Terdapat beberapa area atau ruangan yang dipindahkan agar saling berdekatan dengan area atau ruangan yang seharusnya berdekatan berdasarkan skala prioritas produksi. Seperti contohnya area loading barang didekatkan dengan ruang penyimpanan produk akhir dan area parkir kendaraan. Hal ini dapat mempersingkat jarak tempuh perpindahan barang. Dan contoh lainnya seperti ruangan pendukung produksi dikelompokan pada daerah yang berdekatan. ARD perbaikan ini menjadi bahan pertimbangan pada analisis perancangan berikutnya.

\subsection{Area Allocation Diagram (AAD)}

Setelah didapat ARD usulan perbaikan, selanjutnya dibuatkan AAD. Tujuan dari dibuatkannya AAD yaitu menggambarkan hubungan kedekatan antar departemen dengan sekala ukuran luas area yang sebenarnya dan peletakan lokasi area atau ruangan yang sudah diperhitungkan dari metode ARC dan ARD. Berikut gambaran dasar usulan perbaikan layout pabrik.

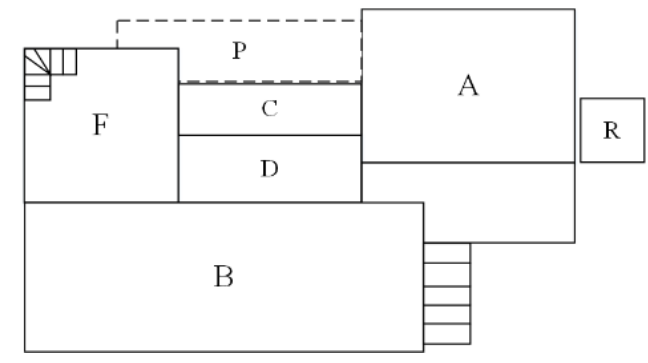

Gambar 5. AAD lantai Basement

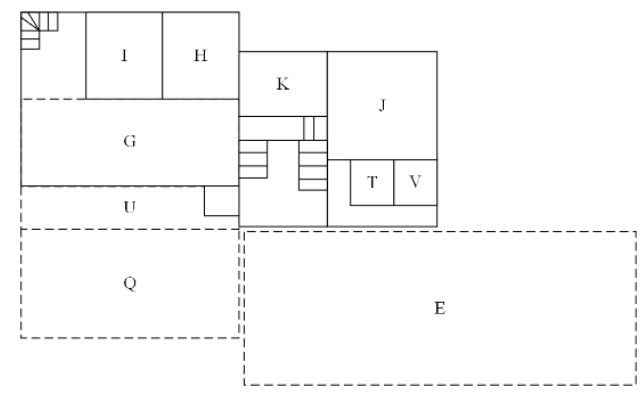

Gambar 6. AAD lantai Dasar

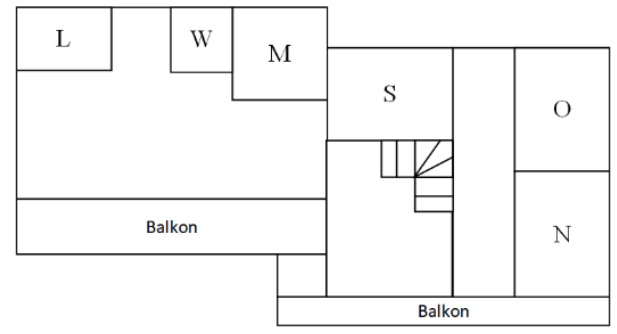

Gambar 7. AAD lantai Dua

Gambaran AAD ini masih berupa block plan sederhana yang masih berupa simbol-simbol huruf namun sudah mendekati perbaikan layout pabrik yang disusulkan sesuai dengan luas dan 
rasio yang sudah ditentukan. Keterangan simbol kode huruf pada AAD terdapat pada tabel 6 .

\subsection{Layout Pabrik Usulan}

Setelah didapat AAD yang masih berupa blockplan, kemudian dapat digambarkan usulan perbaikan dari layout pabrik perusahaan disertai dengan keterangan pintu masuk, akses tangga, dan rasio ukuran ruangan.

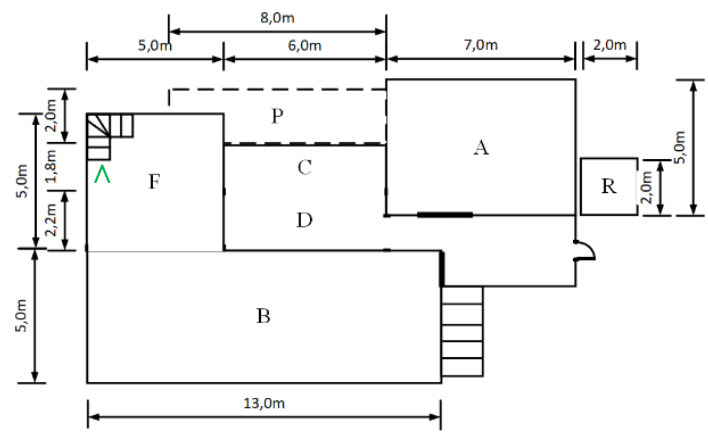

Gambar 8. Perbaikan Layout 1t. Basement

Pada usulan perbaikan lantai basement dikelompokan pada proses produksi yaitu mulai proses penyortiran buah kopi sampai proses pengupasan kulit tanduk biji kopi kering (Hulling). Biji kopi yang sudah dikupas, kemudian dipindahkan ke lantai dasar untuk dilakukan proses berikutnya. Selain itu terdapat juga area penampungan air bersih dan area pengumpulan limbah biji kopi yang harus berdekatan pada proses produksi ini. Terdapat 2 akses tangga menuju lantai dasar, yaitu pada gambar 12 dengan simbol " $\wedge$ ".

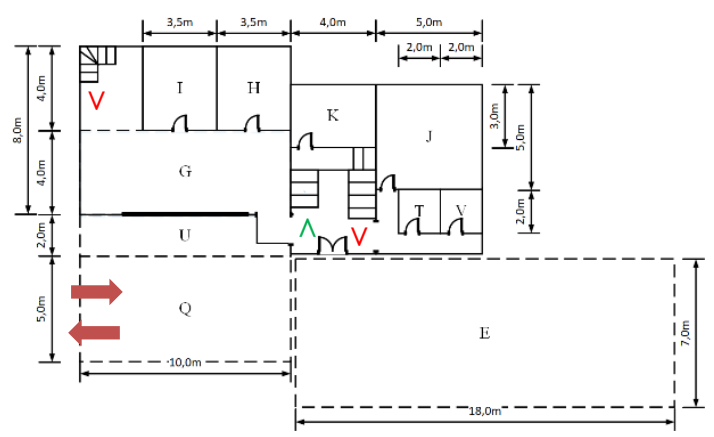

Gambar 9. Perbaikan Layout lantai Dasar

Pada lantai dasar terdapat lanjutan proses produksi mulai dari penyortiran biji kopi berdasarkan grade sampai proses pengangkutan produk. Selain terdapat ruangan produksi, pada lantai dasar ini terdapat area pengeringan, area parkir, dan ruang pendukung produksi seperti ruangan penyimpanan peralatan tani, toilet, ruang penyimpanan BBM, serta ruangan tamu. Terdapat 2 akses tangga menuju lantai basement, yaitu pada gambar 13 dengan simbol " $\bigvee$ ". Sedangkan terdapat akses tangga menuju lantai dua, yaitu dengan simbol “^”. Sedangkan untuk keluar dan masuk area pabrik dengan jalan ditandai dengan simbol panah berwarna merah.

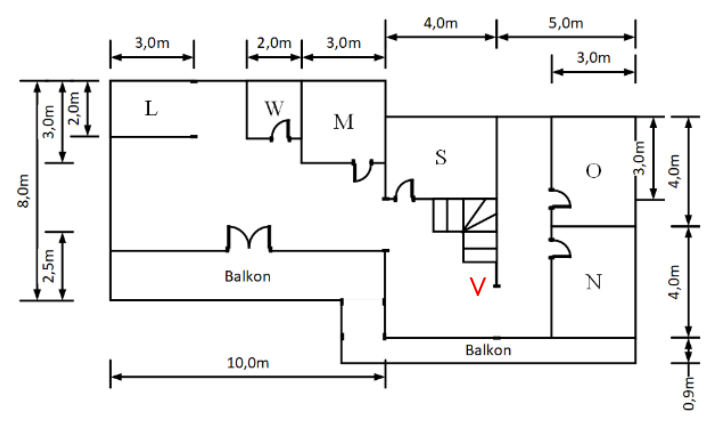

Gambar 10. Perbaikan Layout lantai Dua

Pada lantai dua, tidak ada proses produksi, namun lantai dua dijadikan tempat untuk area atau ruangan pendukung produksi seperti kantor, ruang pegawai, dapur, toilet, dan ruang ibadah. Terdapa akses tangga menuju lantai dasar, pada gambar 14 ditandai dengan simbol " $\bigvee$ ".

Ketiga lantai perbaikan layout pabrik tersebut merupakan hasil akhir dari usulan perbaikan fasilitas produksi dengan mempertimbangan perubahan letak dari area atau ruangan berdasarkan skala prioritas produksinya. Untuk fasiltas produksi utama dan produksi pendukung sudah dikelompokan menjadi berdekatan dan ada juga yang harus dijauhi. Jika diketahui total luasan awal dari bangunan pabrik tersebut yaitu $\pm 1.072 \mathrm{~m}^{2}$, ternyata berdasarkan tabel 7 pertimbangan luas area dan ruangan keperluan proses menunjukan total luas yang diusulkan sebesar $\pm 793 \mathrm{~m}^{2}$ dan masih ada sisa dari luas keseluruhan bangunan sebesar $\pm 279 \mathrm{~m}^{2}$. Kemudian ditambahkan area/ruangan pendukung aktivitas produksi berdasarkan tabel 5 sebesar $40 \mathrm{~m}^{2}$. Sehingga total luasan yang diusulkan sebesar $833 \mathrm{~m}^{2}$.

\section{Kesimpulan}

Dari hasil analisis menggunakan tiga metode yaitu ARC, ARD, dan AAD menghasilkan peta usulan perbaikan tata letak fasilitas produksi. 
Total ruangan yang diusulkan untuk fasilitas produksi dan fasilitas pendukung produksi yaitu berjumlah 21 area/ruangan. Tata letak fasilitas produksi ini dikelompokan berdasarkan proses aliran bahannya. Pada lantai basement terdapat proses penyortiran buah kopi hingga proses hulling kecuali proses pengeringan awal dilakukan pada lantai dasar karena membutuhkan sinar matahari. Kemudia pada lantai dasar terdapat proses lanjutan produksi mulai dari proses penyortiran hinnga proses penyimpanan sementara yang nantinya akan didistribusikan pada sektor hilir perusahaan. Pada lantai dua bangunan pabrik tidak ada aktivitas produksi, hanya terdapat area/ruangan pendukung produksi. Area/ruangan utama ataupun pendukung produksi dan masih menyisakan lahan sebesar $\pm 239 \mathrm{~m}^{2}$ yang dapat dimanfaatkan untuk perkembangan perusahaan kedepannya. Perusahaan diharapkan dapat mengubah tata letak fasilitas produksi pabrik di sektor hulu dengan tujuan untuk meningkatkan produktivitas dan mengurangi ongkos, biaya, dan tenaga produksi.

\section{Daftar Referensi}

Apple, J. M. (1990). Tata Letak Pabrik dan Penanganan Bahan Terjemahan Nurhayati, Mardiono, M.T. Bogor: Institut Pertanian Bogor.

Arif, M. (2017). Perancangan Tata Letak Pabrik (1 st ed.). Yogyakarta: Deepublish.

Badan Pusat Statistik Indonesia. (2018). Statistik Kopi Indonesia 2018. Badan Pusat Statistik /
BPS - Statistics Indonesia. Retrieved from https://www.bps.go.id/publication/2019/12/ 06/b5e163624c20870bb3d6443a/statistikkopi-indonesia-2018

Handoko, A. (2013). Perancangan Tata Letak Fasilitas Produksi Pada UD AHENG Sugar Donut's di Tarakan. Jurnal Ilmiah Universitas Surabaya: Fakultas Bisnis Dan Ekonomika, 1 (2).

Purnomo, B. H., Rudianto, A. S., \& Hamdani, M. (2012). Desain Tata Letak Fasilitas Produksi pada Pengolahan Ribbed...

Rahman, J. F., \& Rahmah, D. M. (2018). Identifikasi Proses dan Strategi Bisnis pada Kadatuan Koffie Menggunakan Analisis SWOT Identification of Business Processes and Strategies in Kadatuan Koffie Using SWOT Analysis, 7, 161-169.

Wignjosoebroto, S. (2009). Tata Letak Pabrik dan Pemindahan Bahan. Surabaya: Guna Widya.

Winarno, H. (2015). Analisis Tata Letak Fasilitas Ruang Fakultas Teknik Universitas Serang Raya Dengan Menggunakan Metode Activity Relationshipchart (Arc). Semnastek. 


\section{LAMPIRAN}

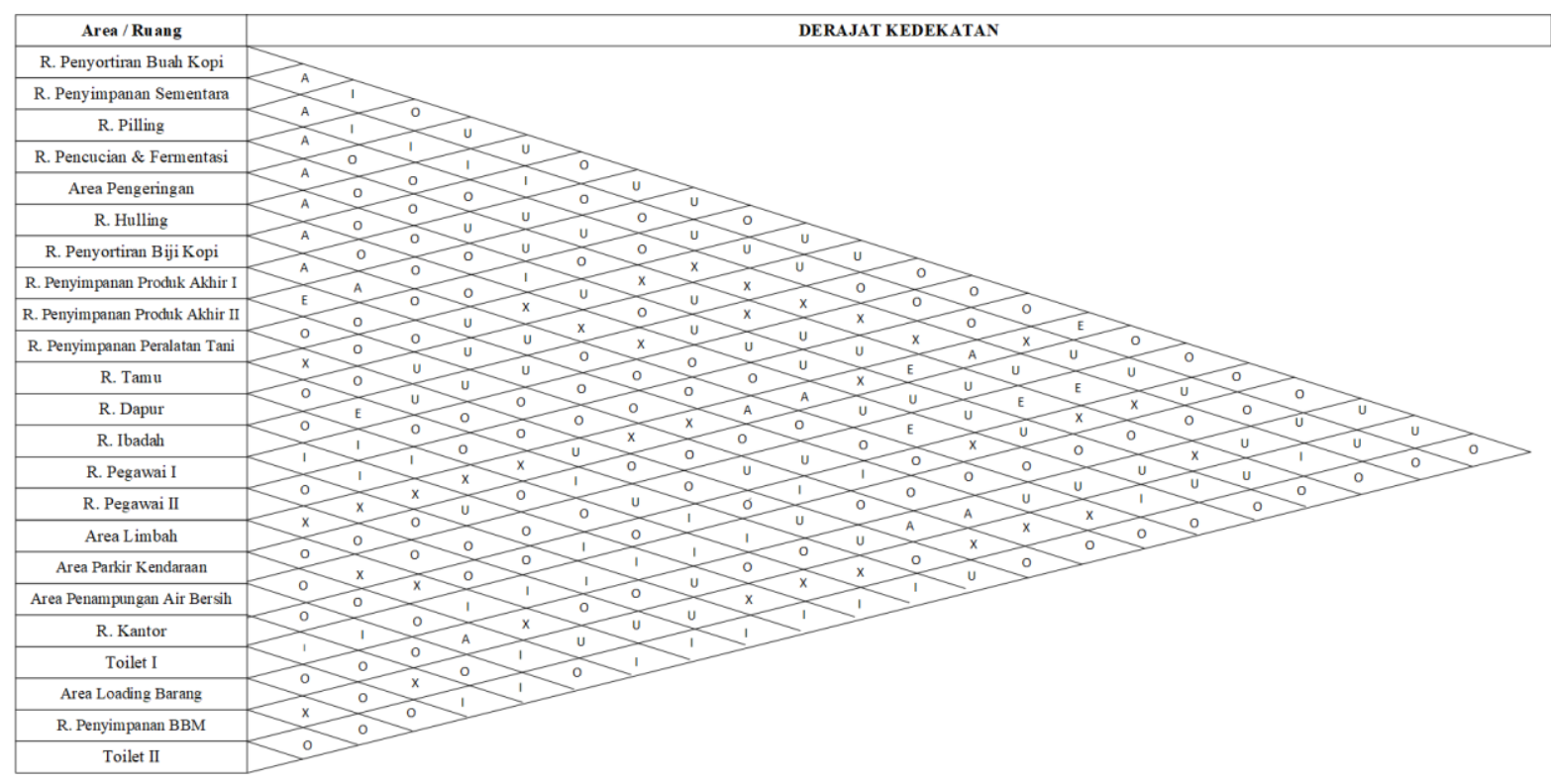

Lampiran 1. ARC Fasilitas Produksi 